\title{
（5）土木学会における地球環境問題への取り組み \\ ACTIVITIES OF JAPAN SOCIETY OF CIVIL ENGINEERS \\ FOR GLOBAL ENVIRONMENT
}

土木学会地球環境委員会

三村 信男*

Nobuo Mimura

\section{[ I ] はじめに}

昨年12月に開かれた地球温暖化防止京都会議(COP3)では、厳しい交渉の末、先進国の温室効果ガス 排出を2008年〜2012年の平均で5.2\%削减することをうたった京都議定書が採択された。この議定書の 採択によって、温室効果ガスの削減に向けた歴史的な第一歩が踏み出されたとする評価がある一方、 温暖化防止の有効性を疑問視する見方が圧倒的である。この目標では、温暖化の進行を止めるには不 十分である上に、2010年頃に温室効果ガス排出が先進国と並ぶ水準に達すると予想されている途上国 と先進工業国との利害の調整も残されている。しかし、京都議定書の採択は、地球環境問題を論じる 時代から解決に挑戦する時代へと大きく世界が動きだしたことを象徴的に表している。

土木学会は1990年代初めから, 活発に地球規模環境問題の研究に取り組んできた。こうした時点に たって、具体的に地球環境問題解決に向けて何が出来るのかを、改めて考えたい。

\section{[II ] 土木学会と地球環境問題}

\section{1. 土木技術と地球環境問題の関わり}

\section{(1)わが国の土木技術}

日本の国土は70\%以上が山地であり，そこに源を発する河川は急流として降雨や洪水，土砂，陸域 の物質を海に向けて運搬している. 平地は, 海岸付近の沖積平野や河川の氾濫源に限られ, 狭い地域 に人口や資産，社会・経済活動の大部分が集中している．また，中緯度に位置し四方を海に囲まれて いるため, 多彩な自然環境に恵まれている反面, わが国は台䖝, 集中豪雨・豪雪, 洪水, 高潮, 地震, 津波, 地滑り等といった自然災害に悩まされてきた.

こうした地理的自然的条件を背景にして, わが国では古くから治山, 治水そして農業等の基盤整備 を図る土木技術の発展が国土形成にとって不可欠の条件であった. 近代以降においても，土木技術の 中心的な使命の一つは国土保全と防災であり, 達成されてきた成果は, 住民の安全な生活を保障する 土台になっている，さらに，土木技術は産業や国民生活の活動基盤を提供するために大きな役割を果 たしている，戦後，国土の復旧と経済成長を目指して新幹線や高速道路，港湾，空港等の交通インフ

*茨城大学 広域水圈環境科学教育研究やン多 Center for Water Envi roment Studies, Ibaraki Univ. 
ラやエネルギー施設，水道，地下開発，人工島など多様な社会基盤の整備が進められてきた.

これらは自他共に認める土木技術の歴史的役割である. しかし, 地球環境問題という新しい視点で

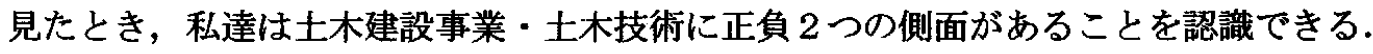

\section{(2)土木建設事業の地球環境負荷}

地球温暖化にとって土木建設業は, 環境負荷を与える経済活動の 1 つである. わが国では, 土木建 設業はGDPの約1/5を占める大きな産業となっており，それに対応してエネルギーの消費及び二酸化 炭素の排出という点でも大きな割合を占めている.

また, 地球環境問題が提起した問題の一つに，地域から地球規模まで自然生態系をどう保護，保全 するかという問題がある。わが国でも，道路の建設や河川改修，住宅団地の建設等によって生物の生 息域が後逐したといわれることが多い. 防災にせよ開発にせよ土木建設工事をすれば何らかの自然環 境の改変は不可避であるが，これは自然に直接対侍し働きかける土木分野の特性である.この問題に ついても，土木建設業の地球環境負荷としてよりよい対応への努力が必要である.

(3)環境保全工学としての土木工学

他方, 現在の土木工学は環境保全工学としての役割を担っている. 下水道や廃棄物処理などいわゆ る静脈系の社会基盤の整備や生態系の保全とインフラ施設の整備との調和を図るのも土木工学の役割 である. 地球環境問題の解決を考えた場合, 環境保全工学としての土木技術の展開が必要である.

\section{2. 土木学会の活動}

地球環境問題が注目され始めた時, 土木学会は, いち早く行動を始めた。1989年頃から様々な常置 委員会（土木学会の活動の基礎単位をなす委員会）で地球環境問題への取り組みが模索され始めた. 1991年には学会としてこの問題に取り組むために「土木学会地球環境委員会」が設立された. 土木学 会としてこのような体制を確立したのは，地球環境問題が人類の未来にとって極めて重要な課題にな ると認識したからである.

その後, 土木学会は, 地球サミットの精神と呼びかけに答えて, 1994年に「土木学会地球環境行動 計画ーアジェンダ 21 土木学会」を策定した. この行動計画は, 土木学会の過去の経験を踏まえなが ら, 未来に向かって自らの課題を示したものであった.アジェンダ 21 土学会はその後, 要約版と 英語版が作成され，大学や高専での教育や国際的な交流に利用されている.

地球環境問題に対する取り組みは, 個々の分野において日常的, 継続的に進めることにこそ意味が ある. 土木学会における活動は, 地球環境委員会を中心に, 広く様々な常置委員会で取り組まれてい る(表-1).

\section{3. 地球懪境問題に対する土木学会の方針ーアジェンダ 21/土木学会が揭げたものー}

\section{1)地球璒境の改善に貢献する土木工学の形成}

土木工学と地球環境問題の関係には正負の二面性があるが，その解決は土木技術の寄与なくしては 達成できない，そうした自覚に立って，土木事業と地球環境との関わりを常に研究しながら, 地球環 境と社会・文化に対して最適な社会基盤を整備するシステムを探求する. 
表-1土木学会の取り組みの経過

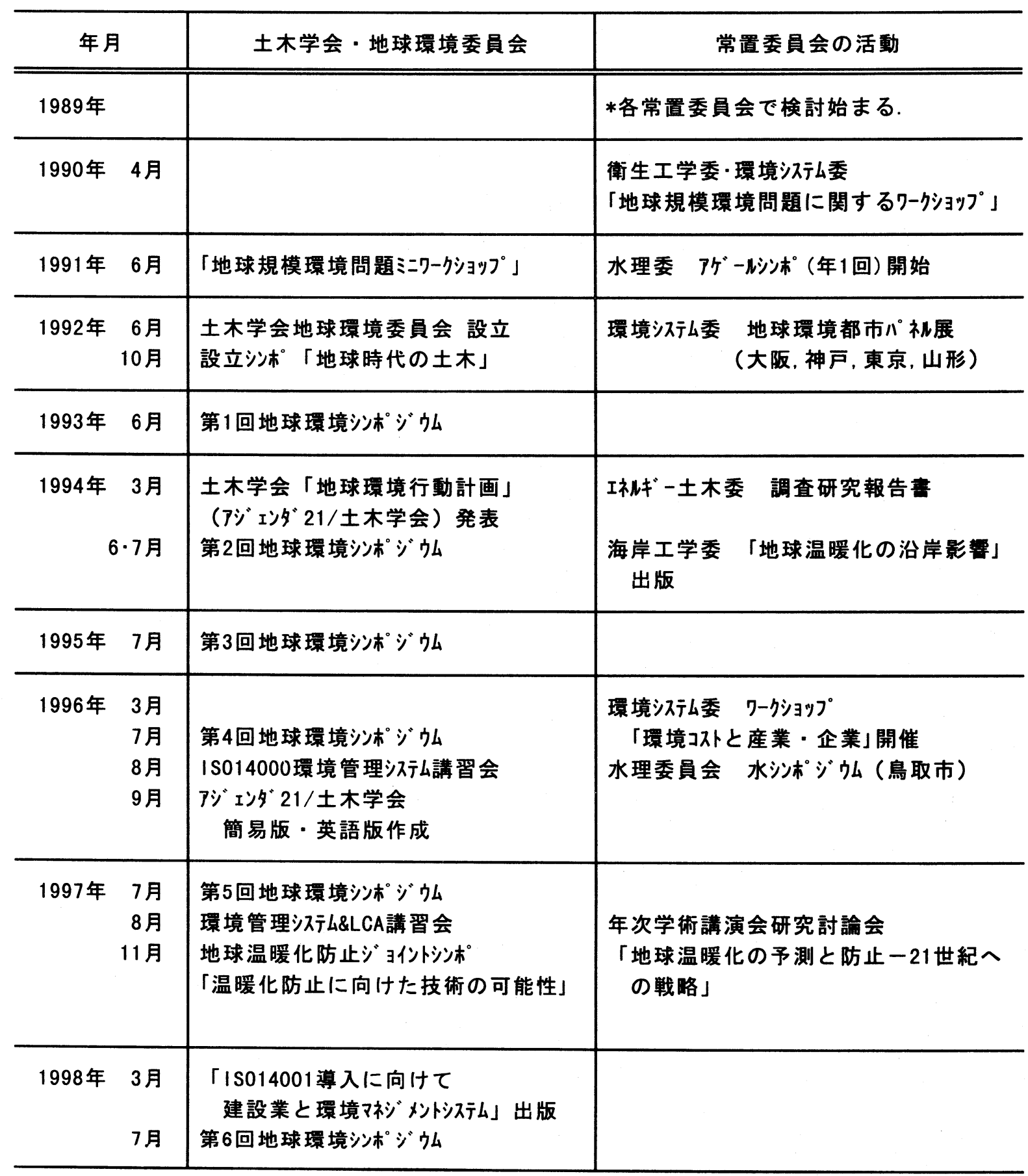

2)人類と生物の共存を可能にする新しい土木工学の展開

生物環境の保全を抜きに持続的な開発は成り立たないという認識に基づいて，生物多様性の保全を 目的に，生物との関わりを組み込んだ新しい土木工学の展開を図る。この中には，開発に伴う自然破 壊の補填としてのミチゲーションを含めた環境創造という方向性も含まれている.

3)温暖化・気候変動の影響構造の解析と対応技術・システムの開発 地球温暖化・気候変動は長く自然と向き合ってきた土木工学がその蓄積を生かすべき分野である. 
温暖化・気候変動による海面上昇, 水文循環の変化, 砂漠化などの発生機構と影響の評価に一層取り 組む. このために, 地球科学分野と協力すると共に, 防災, 土㙵侵食対策, 水資源開発, 沿岸環境保 全等の領域で対応技術を開発する.

\section{4)资源循環型国土・都市づくりの技術開発}

地球温暖化をはじめ地球環境問題の解決は，結局は日本全体あるいは地域全体の構造が省エネル ギー・省資源型になるかどうかに大きく依存している．これまでの大量消費, 使い捨ての生産消費構 造を, リサイクルを始め人間活動の負荷を最小化する方向に転換しなければならない. さらに; 環境 共生都市という理念も打ち出されている. 省エネルギー・省資源・凟源循環型の地域, 罣境共生都市 の計画手法とそれを可能にする技術，材料技術の開発に取り組む.

\section{5)酸性雨, 海洋污染等種々の地球環境問題の解決に貢献する土木工学の構策}

土木工学が貢献できる問題は，大きく広がっている．酸性雨，海洋污染，人口・食糧問題などあら ゆる地球環境問題の解決に貢献する土木工学の構筑を図る.

\section{6)国際的な指針と技術の開発}

わが国の土木技術は今後国際的な場で貢献が求められることが多くなると予想される．そのために， 必要な国際的に通用する指針の構筑や日本の土木技術を途上国などの国情（自然，風土，社会経済） に適合した技術に発展させる.

\section{[III］土木工学と地球温暖化}

温暖化防止京都会議の結果を受けて、とりわけ温暖化防止に向けて私達がどのような取り組みを行 う必要があり、どのような可能性を持っているのであろうか。以下では、その点を検討する。

\section{1. 温室効果ガスの排出量}

(1)わが国の部門別排出量

図-1は，環境庁推計によるわが国の1994年度のCO ${ }_{2}$ 排出量とそのシェアを示したものである.これ によると、発電などのエネルギー転換部門転換部門で7.7\% 産業部門で33.9\% 民生部門（家庭）で $12.57 \%$ 民生部門 (事務所等) で11.37\% 運輸部門で19.2\%等となっている. 米国に比較して日本で は産業分野でのCO ${ }_{2}$ 排出量のシェアが高く, 民生, 運輸部門でのシェアが低い. しかし, 伸び率でみ ると, 産業部門に比べて民生, 運輸部門の上昇が著しい.

その他の温室効果ガスであるメタンの排出量は 155 万トで, 農業部門で $59 \%$ 廃棄物埋立や下水処理 で24\%，燃料燃焼等で2\%を占めており，亜酸化窒素の排出量は11万トでエネルギー転換・産業部門で $85 \%$ 農業で $8 \%$ ，廃棄物で®\%と推計されている.

建設分野に関連する二酸化炭素の発生原因は, 構造物の建設, 鉄銅・セメント等の資材生産や建設 機械の製造，建設活動に伴う輸送などがあげられる. 建設業に関連する活動を全てとらえると，エネ ルギー消費ではわが国全体の約37\%を占めており，このうち建設資材の製造が9\%こなっている. 一方， 二酸化炭素の発生量でみると, わが国全体の34\%に達しており, 建設分野での対応の重要性が指摘で きる. 


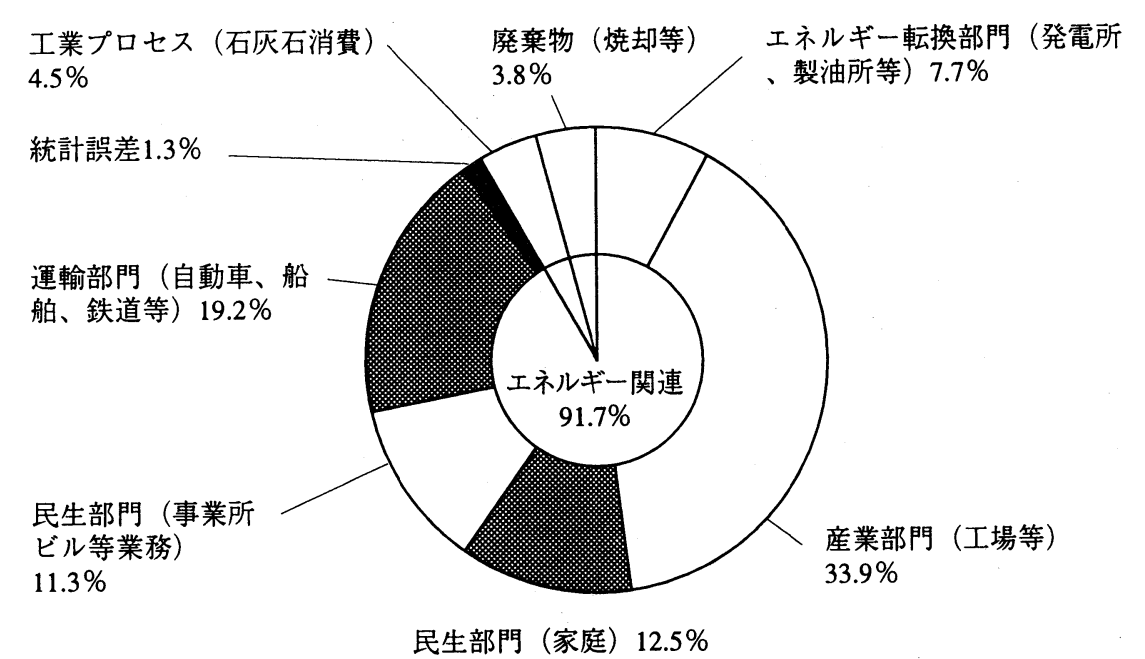

図-1わが国の温室効果気体の排出源（平成6年度、平成9年度環境白書）

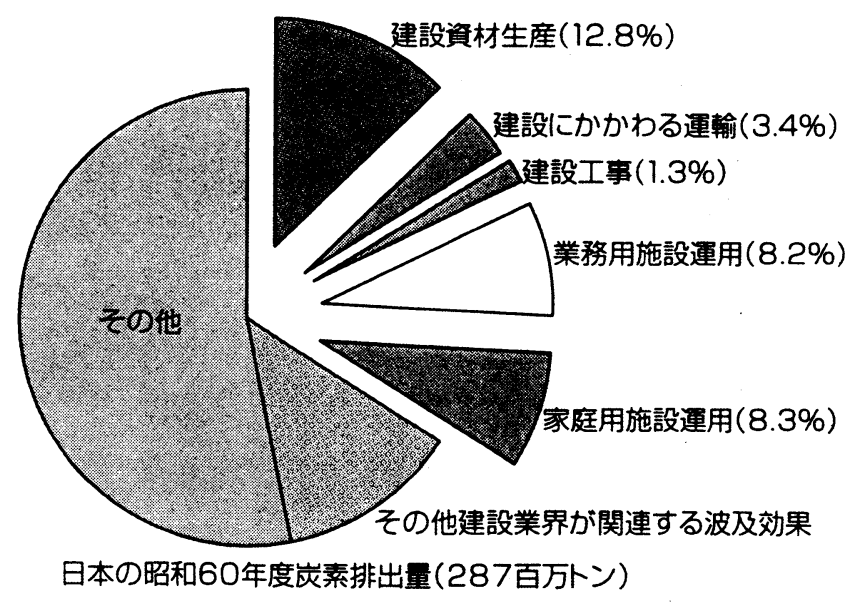

図-2 建設業から $\mathrm{CO}_{2}$ 排出割合

\section{2. 地球温暖化防止にむけた土木工学の課題}

温暖化防止のためには，今後長期的な取り組みが必要になる．温暖化防止のためには，温室効果ガ スの排出抑制が第 1 の課題である. 同時に, 都市インフラ施設群の安全性・機能の確保との両立や温 暖化の影響への備えなども考慮すべき課題である. このような複雑な目標を達成するためには個別技 術だけでなくシステムとして対応策を組み立てていく必要がある. 土木界として, 次のような分野で それに貢献することができる.

\section{1)建設事業からの温室効果ガスの排出削诚}

建設事業における温室効果ガスの発生では，建設資材の生産とその輸送の寄与が大きい，そのため, それらの抑制や循環，省エネルギー技術・システムの開発が必要である．また，それらの基礎となる 
ライフサイクル評価や環境管理システムの導入が必要である.

一建設資材の生産の省エネルギー化技術，循環系の確立

一建設資材や建設発生土の輸送の省エネルギー化技術・システム

一建設工事の省エネルギー化技術・システム（省資源化，省資源設計など）

一温室効果ガスの排出を最小に抑えるライフサイクル評価

\section{建設業からのCO 排出量とライフサイクル評価}

土木工事では鉄鋼とコンクリートを大量に使用するが，これらの資材製造段階で発生するCO 2 は, 構造物のライフサイクル全体でのCO 2 発生量の中で70 80\% と非常に大きな割合を占める. 個々の 材料の二酸化炭素発生原単位を表-3に示す。この表から分かるとおり, リサイクル材による電気炉 鋼や高炬セメントでは， $\mathrm{CO}_{2}$ 排出量を大幅に削減できる．また，石材や木材のような天然素材は素 材加工が単純であり，それだけ $\mathrm{CO}_{2}$ 排出量が少ない.

こうしたことから，地球温暖化防止のためには以下のような対応が考えられる.

(1) 使用材料の削減

(2) 環境負荷の小さい資材の選択

(3) 資材を使用する構造形式の選択

$\mathrm{CO}_{2}$ 排出量の削減の観点から, 設計, 施工, 維持管理, 撤去という構造物のライフサイクルを通 した排出量の把握と削減に関する研究が取り組まれている.

\section{建設資材の循環系の確立}

現在の建設工事のうち既存建物や施設の除去を伴う更新工事の比率は25\%程度である. しかし， 2010年には過半が更新工事となると予想されており，戦後建設された都市インフラ施設の更新に 伴って大量の建設廃棄物が発生してくることになる.

建設資材の循環系の形成は，こうした実情から，建築・土木構造物に蓄積された膨大な建設資材 をどのように循環利用し，省エネルギーを図るか，という課題を負っている．さらに，年間12億卜 ンもの建設資材と建設廃棄物，4億トンを超える建設発生土の循環体系を運搬に伴うエネルギー消 費を抑える視点から，資源循環系を構築することが課題である. 特に，温室効果ガスの排出量の多 い鉄鋼およびコンクリートでは，建設資材の循環系を関連産業上の連携で構築していかねばならな い.

\section{2)社会基盤施設（都市インフラ）の運用からの温室効果ガスの排出削減}

土木事業の成果は, 社会基盤施設である. 完成した施設の運用から発生する温室効果ガスの抑制が 第 2 の課題である. 都市インフラでは, 水道, エネルギー供給システム, 下水道システム, 廃棄物処 理・処分施設での省エネルギー対策や処理工程からのメタンなどの排出抑止などが必要である. 更に, 共同溝など土木工事の削減に繋がる都市インフラの整備促進などもこの分野の対応課題となる.

一方, 建築面では, 省資源型・省エネ型の建築技術の開発も課題となる. 住宅やビルの高気密・高 断熱化や屋上・壁面緑化, 地区緑化, 住宅設備やビル設備（エレベーター・冷暖房・給湯システムな ど）の高効率化, 太陽光・熱を中心とする自然エネルギーの利用システム, エコスーパーやワン・ス トップ・ショップなどの分野での研究や展開が求められる. 


\section{3)交通・運輸分野からの温室効果ガスの排出削娍}

運搬分野での温室効果ガスの削減面では, 省エネルギ一型の物流や交通体系をどのように国土, 都 市域で展開するかについての計画手法の開発やそれを可能とする技術, システムの開発こそ土木界が 担うべき課題である.これらの実現には長期的な視点が必要であり, 計画手法面では, 運搬需要を削 減するための国土や大都市圈構造, 全国れレベルあるいは都市圈での物流, 交通体系の再編が求めら れる.

電気自動車等の非化石燃料自動車の普及には, 充電・燃料補給ステーションの整備が必要となり, 更に海上輸送への積み替え基地などを含めた物流拠点の適正配置, バス専用レーンの整備, 交通規制 の導入, 自転車道や駐輪施設の整備, 職一住近接, サテライトオフィス, 情報システムの活用もこの 地域展開上の課題である.

\section{交通・運輸分野での対策}

わが国では1973年から1994年の20年間に, 全部門平均の二酸化炭素排出量は約1.2倍にとどまっ ているのに対して，運輸部門では約1.9倍増加している.こうした増加の原因は, 自動車の増加に 起因している．1991年における運輸部門からの二酸化炭素排出量のうち87.5\%が自動車によるもの と推計されている.

交通・運輸部門からの二酸化炭素削減には，交通システムの構成主体からみて，次のような対応 策が考えられる.

(1) 移動主体への働きかけ: 啓発活動

(2) 交通路の有効利用：モーダルシフト（鉄道や船の利用），渋滞対策など

(3) 交通具の改善 : 燃料・エンジン技術の向上, 電気自動車など

(4) 交通システム全体の対策 : 国土・都市計画，土地利用規制，課徵金，炭素税など

\section{4)エネルギー供給分野での対応策}

エネルギー転換・供給分野では，コージェネレーション・燃料電池・蓄熱・蓄電システム技術，自 然エネルギー（太陽光・水力・風力・波力・地熱・バ仏久 等）発電, 未利用エネルギー（廃棄物, 下水, 環境熱等）の活用技術の開発が進められている. 土木分野では，これらの技術・システムを地 域に導入促進する面での対応が求められている. 即ち, 従来の電力や都市ガスでのエネルギー供給に 加えて，これらの技術・システムを組み込んだ地域エネルギー供給システムが求められている.

\section{5)廃棄物処理分野からの温室効果ガスの排出削減}

廃衰物処理分野では, 焼却処理による二酸化炭素, 埋立処分によるメタンの排出などが温室効果ガ ス排出量の $2 \%$ 程度のシェアを占めていることが報告されている.この廃棄物の処理・処分技術につ いては，これまでも土木学会の環境工学分野が深く関わってきており, 今後ともその削減技術の開発 や展開への対応が期待されている.

\section{6)国土計画・都市づくりでの対応策}

長期的なエネルギ一需要の削減には国土構造の再編が不可欠である. 多極分散型国土形成, 産業立 地, 森林や農地・内水面保全, 基幹交通体系の構築などを進めるための国土計画分野は土木界が中心 


\section{に担うべき課題である.}

また，省エネルギー型都市・地域づくりにおいても次のような対応課題が挙げられる.

一浸透舗装、人工水面、屋上・壁面緑化などのヒートアイランド対策技術の開発や展開

一省エネルギー型物流、都市インフラ、自然エネルギー・未利用エネルギーの活用体系 の地域展開を進めるための都市計画、都市づくり手法の開発とその展開

一エコタウン計画などの環境共生型都市づくりの計画面での支援技術・システム開発

\section{7)温暖化影蓄の研究と䔔度対策}

温暖化は気候変動や海面上昇などをもたらす，海面上昇の沿岸環境への影響, 気候変動の水文影響 などの研究は, 河川工学, 海岸工学, 海洋工学, 土質工学などの領域での展開が期待されている.ま た，影響緩和対策では，気候変動に伴う砂漠化の防止や水源対応方策と支援技術の開発，海面上昇 の対応技術の開発が期待され，特に途上国への技術協力が求められている.

\section{8)建設羓におけるる聚境管理システムの確立}

持続可能な開発の実現を揭げて，産業各分野で環境管理システムの構築が目指されている．国際的 にはISO14000シリーズとして，標準化が進んでいる．温室効果ガスの排出抑制はもちろん，水質污濁， 大気污染, 騒音, 振動などの環境污染を防止し, 自然との共生を進めるために, 土木建設業において も，包括的な環境管理システムの確立を目指す必要がある.

\section{9)途上国一の協力・支援}

地球環境の影響は対応基盤の弱い途上国に厳しい，また，途上国では今後の人口増加，経済発展を 背景に建設事業の急速な拡大が予想されることから，温暖化防止技術の移転面でも土木界の対応が求 められることになろう，さらに，経済発展，環境公害対策，地球噮境問題の解決を可能にする途上国 の土木工学の発展とそれを支える土木技術者・研究者の盖成を支援する必要がある.

\section{[IV] おわりに}

最初にも述べたように、地球環境問題は、解決に向けた行動の時を迎えている。しかも、地球温暖 化のように、最終的には社会構造やライフスタイル、それ、支える地域の構造の変化が必要とされて おり、解決策の構築と実現には長い年月を要する。こうした道筋の中では、土木工学が果たす役割も 小さくない。これに応えるために，今後も土木界以外の方々と意見を交わし，様々な分野の方々と協 カしながら, 私達の専門知識と技術を生かす道を追求したいと考えている. 